\title{
Laparoscopic vs open gastrectomy- An updated metanalysis of randomized control trials for short term outcomes.
}

Dr.Bhavin Vasavada

Consultant Hepatobiliary and liver transplant surgeon,

Shalby hospitals,

Ahmedabad, India

Email:drbhavin.liversurgeon@gmail.com

Dr.Hardik Patel.

Consultant Hepatobiliary and liver transplant surgeon,

Shalby hospitals,

Ahmedabad, India

Keywords: Metaanalysis, Gastrectomies, gastric cancers

Abbreviations:RCT (randomized control trial), Weighted Mean Difference (WMD), Confidence Intervals.(C.I),SD (Standard deviations)

Conflict of interests:none

Financial disclosures:none

\section{Abstract:}

\section{Introduction:}


Aim of this metanalysis was to compare short term outcomes of laparoscopic and open gastrectomy for gastric cancer.

\section{Material and methods:}

EMBASE, MEDLINE, PubMed and the Cochrane Database were searched for randomized control trials comparing outcomes in patients undergoing laparoscopic gastrectomies with those patients undergoing open gastrectomies. The primary outcome was 30 days morbidity and mortality. Secondary outcomes studied included length of stay, blood loss, d2gastrectomies, lymph node retrieval, operative time, distal gastrectomy, wound complications and intraabdominal complications Systemic review and Metanalysis were done according to MOOSE and PRISMA guidelines.

\section{Results:}

Morbidity was significantly low in laparoscopic $\operatorname{group}(\mathrm{P}=0.003)$. There was no significant difference between mortality between the two groups. $(\mathrm{P}=0.75)$. There fewer wound complications in laparoscopic group, no difference intra-abdominal complications in both the groups. Blood loss was significantly lesser in laparoscopic group.(p <0.001). Hospital stay was similar in laparoscopic group. $(\mathrm{P}=0.30)$. Operative time was significantly higher in laparoscopic group.( $\mathrm{P}<0.001)$. Laparoscopic group patients had less number of lymph node retrieval compared to laparoscopic group. $(\mathrm{p}=0.002)$. Laparoscopic group also contained similar advanced staged gastric cancer than open gastrectomies. $(p=0.64)$

\section{Conclusions:}


Laparoscopic gastrectomies were associated with better short term outcomes.

\section{Introduction:}

With advancement of technology and skills laparoscopic gastrectomy is increasingly being performed. However, there is still some debate over short term outcome, oncologic safety of resections and long-term survivals in comparison to standard open gastrectomies.[1]. Initially laparoscopic gastrectomy was reserved for early and distal laparoscopies but these days more and more surgeons are performing laparoscopic gastrectomies via open approach also. [2].

\section{AIMS OF STUDY:}

Aims of this metanalysis to do analysis of recent randomized control trials regarding short-term outcomes.

In short term outcomes aim was to study morbidity and in hospital mortalities as wells as hospital stay, blood loss, operative times as well as to study oncological parameters like D2gastrectomies, number of lymph node retrieval D2gastrectomies, number, resection rates for advanced gastric cancers.

\section{Material and methods:}

EMBASE, MEDLINE, PubMed and the Cochrane Database were searched for randomized control trials comparing outcomes in patients undergoing laparoscopic gastrectomies with those patients undergoing open gastrectomies and studies 
comparing long-term survival outcomes. Two independent authors extracted the data (B.V and H.P). Discussions and mutual understanding resolved any disagreements. Systemic review and Metanalysis was done according to MOOSE and PRISMA guidelines. $[14,15]$. Types of studies included in metanalysis is described in table 1.

\section{Statistical analysis}

The meta-analysis was conducted using Open meta-analysis software. Heterogeneity was measured using $\mathrm{Q}$ tests and $\mathrm{I}^{2}$, and $\mathrm{p}<0.10$ was determined as significant (8). If there was no or low heterogeneity $\left(\mathrm{I}^{2}<25 \%\right)$, then the fixed-effects model was used. Otherwise, the random-effects model was used. The Odds ratio (OR) was calculated for dichotomous data, and weighted mean differences (WMD) were used for continuous variables. Both differences were presented with 95\% CI. For continuous variables, if data were presented with medians and ranges, then we calculated the means and Standard deviations according to Hozo et al. (16). If the study presented the median and inter-quartile range, the median was treated as the mean, and the interquartile ranges were calculated using 1.35 SDs, as described in the Cochrane handbook.

\section{Inclusion criteria for studies:}

- $\square$ Randomized control trials for short term outcomes.

- $\quad \square$ Studies comparing laparoscopic and open gastrectomies.

- $\square$ Full text articles.

\section{Exclusion criteria for studies:}

- $\quad \square$ Nonrandomized control trials for short term outcomes.

- $\square$ Studies with single groups or studies in which groups were not 
comparable.

- $\square$ Studies where full texts were not available

- $\square$ Duplicate studies.

\section{Assessment of Bias:}

Characteristics of the studies are described in table 1. [3-13,19-26]. Randomized trials were assessed based on the Cochrane Handbook. [18] (Figure 2). We evaluated publication bias by funnel plots for each parameter.

\section{RESULTS:}

Selection process of studies for short term and long-term outcomes for this metaanalysis is described in Figure 1.

For short-term outcomes 11 RCTS consisting of 4614 patients were included in study. Total 2452 patients were there in laparoscopic gastrectomy group while 2162 patients were included in open gastrectomy group. Morbidity is defined as any deviation from normal perioperative course.

Postoperative morbidity was significantly low in laparoscopic group. $(\mathrm{P}=0.03)$. There was no significant difference between mortality between the two groups. (P=0.75). [figure 3]

Wound complication was significantly less in laparoscopic group $(\mathrm{p}=0.009)$, other intra-abdominal complications were in both the groups. $(\mathrm{P}=0.18)$. [figure 4] 
Blood loss in ml was significantly lesser in laparoscopic group. $(\mathrm{p}<0.001)$. Hospital stay in days was not significantly different in laparoscopic group. $(\mathrm{P}=0.30)$. Operative time in minutes was significantly higher in laparoscopic group. $(\mathrm{P}<0.001)$. [figure 5] Laparoscopic group patients had similar $\mathrm{d} 2$ gastrectomies $(\mathrm{p}=0.26)$ and less number of lymph nodes retrieved compared to laparoscopic group.(p=0.002), Laparoscopic group also undergone similar advanced staged gastric cancer (T2 and higher) than open gastrectomies. $(\mathrm{p}=0.640)$. [figure 6]

\section{DISCUSSION:}

Laparoscopic surgeries have shown similar results to open surgery with improved perioperative outcomes in many malignant diseases. [26-30]. With time laparoscopic approaches have gained more popularity for gastric cancers. [31-32]

Aim of our study was to perform updated meta-analysis of recent randomized control trials for short term outcomes comparing laparoscopic vs open gastrectomies. For long term out comes there are not enough randomized control trials for long term survival outcomes. So we performed meta analysis of cohort studies for long term survivals.

90 days morbidity was significantly less in laparoscopic group however on subgroup analysis there was no difference in Local complications (leak, fistula , collection), wound complications (SSI) were significantly lesser in laparoscopic group. Our findings do suggest that benefit of laparoscopic surgeries in short term morbidities..

There was no difference in 90 days mortality between the two groups. Operative time was significantly higher in laparoscopic group, intraoperative blood loss was significantly less in laparoscopic group, suggesting that laparoscopic surgery is 
beneficial in short term outcomes. However there was no significant difference in hospital stay.

There has always been doubt about oncologic safety and adequacy of laparoscopic surgeries. Our meta analysis also gave similar findings, There was significantly lesser number of total number of lymph node retrieval in laparoscopic group. Many recent studies showed oncologic benefit of $\mathrm{d} 2$ vs $\mathrm{d} 1$ gastrectomies. [33,34]. Long term impact of these findings needs to be evaluated.

There are certain limitation in our analysis. Heterogeneity was significant in some parameters as seen in some forest plot. Some parameters showed publication bias as shown by funnel plots.

In conclusion Laparoscopic gastrectomies were associated with better short term outcomes. However long-term survival rate needs to be evaluated by randomized control trials and further metanalysis.

\section{Refrences:}

1. Son T, Hyung WJ. Laparoscopic gastric cancer surgery: Current evidence and future perspectives. World J Gastroenterol. 2016 Jan 14;22(2):727-35.

2. Deo SV, Puntambekar SP. Laparoscopic radical distal gastrectomy for ca stomach. Indian J Surg. 2013 Jun;75(Suppl 1):368-72

3. Lee HJ, Hyung WJ, Yang HK, Han SU, Park YK An JY et al. Shortterm Outcomes ofa Multicenter Randomized Controlled Trial Comparing LaparoscopicDistal Gastrectomy With D2 Lymphadenectomy to Open Distal Gastrectomy for Locally AdvancedGastric Cancer (KLASS-02-RCT). Ann 
Surg. 2019 Feb 9. doi: 10.1097/SLA.0000000000003217. [Epub ahead of print].

4. Cai J, Wei D, Gao CF, Zhang CS, Zhang $\quad$ H, Zhao T.

A prospective randomized study comparing open versus laparoscopyassisted D2 radicalgastrectomy in advanced gastric cancer. Dig Surg. 2011;28(5-6):331-7.

5. Huscher CG, Mingoli A, Sgarzini G, Sansonetti A, Di Paola M, Recher A, et al.Laparoscopic versus open subtotal gastrectomy for distal gastric cancer: fiv e-year results of a randomized prospective trial. Ann Surg. 2005 Feb;241(2):232-7

6. Cui M, Li Z, Xing J, Yao Z, Liu M, Chen L, et al. A prospective randomized clinical trial comparing D2 dissection in laparoscopic and open gastrectomy for gastric cancer. Med Oncol. 2015 Oct;32(10):241.

7. H. Hayashi,T. OchiaiH, ShimadaY.,Gunj. Prospective randomized study of open versus laparoscopy-assisted distal gastrectomy with extraperigastric lymph node dissection for early gastric cancer. Surg Endosc (2005) 19: 1172

8. Hu Y, Huang C, Sun Y, Su X, Cao H, Hu J et al. Morbidity and Mortality of Laparoscopic Versus Open D2 Distal Gastrectomy for Advanced Gastric Cancer: A Randomized Controlled Trial. J Clin Oncol. 2016 Apr 20;34(12):1350-7.

9. Katai H, Mizusawa J, Katayama H, Takagi M, Yoshikawa T, Fukagawa T et al. Short-term surgical outcomes from a phase III study of laparoscopyassisted versus open distalgastrectomy with nodal dissection for clinical stage IA/IB gastric cancer: Japan Clinical OncologyGroup Study JCOG0912. Gastric Cancer. 2017 Jul;20(4):699-708. 
10. Kim W, Kim HH, Han SU, Kim MC, Hyung WJ, Ryu SW et al. Decreased Morbidity of Laparoscopic Distal Gastrectomy Compared With Op en DistalGastrectomy for Stage I Gastric Cancer: Short-term Outcomes From a Multicenter Randomized Controlled Trial (KLASS-01). Ann Surg. 2016 Jan;263(1):28-35.

11. Kitano S, Shiraishi N, Fujii K, Yasuda K, Inomata M, Adachi Y. A randomized controlled trial comparing open vs laparoscopy-assisted distal gastrectomy for the treatment of early gastric cancer: An interim report. Surgery. 2002 Jan;131(1 Suppl):S306-11

12. Lee JH, Han HS, Lee JH. A prospective randomized study comparing open vs laparoscopy-assisted distal gastrectomy in early gastric cancer: early results. Surg Endosc. 2005 Feb;19(2):168-73

13. Takiguchi S, Fujiwara Y, Yamasaki M, Miyata H, Nakajima K, Sekimoto M, Laparoscopy-assisted distal gastrectomy versus open distal gastrectomy. A prospective randomized single-blind study. World J Surg. 2013 Oct;37(10):2379-86

14. Stroup DF, Berlin JA, Morton SC, et al. Meta-analysis of observational studies in epidemiology: a proposal for reporting. Meta-analysis Of Observational Studies in Epidemiology (MOOSE) group. JAMA. 2000 Apr $19 ; 2008-12$.

15. Liberati A, Altman DG, Tetzlaff J et al. The PRISMA statement for reporting systematic reviews and meta-analyses of studies that evaluate health care interventions: explanation and elaboration. J Clin Epidemiol. 2009 Oct; e1-34.

16. Hozo SP, Djulbegovic B, Hozo I (2005) Estimating the mean and variance 
from the median, range, and the size of a sample. BMC Med Res Methodol $5: 13$.

17. Wells G, Shea B, O'Connell D, et al. The Newcastle-Ottawa Scale (NOS) for assessing the quality of nonrandomised studies in meta-analyses. September 1, 2016.

18. HigginsJP, AltmanDG, GøtzschePC,et al. TheCochraneCollaboration'stool for assessing risk of bias in randomized trials. BMJ. 2011;343: d5928.

19. Kim HH, Han SU, Kim MC, Kim W, Lee HJ, Ryu SW et al. Effect of Laparoscopic Distal Gastrectomy vs Open Distal Gastrectomy on Long-term Survival Among Patients With Stage I Gastric Cancer: The KLASS-01 Randomized Clinical Trial. JAMA Oncol. 2019 Feb 7. [Epub ahead of print]

20. Zhengyan Li, Bofei Li, Bin Bai, Pengfei Yu, Bo Lian,Qingchuan Zhao $\square$.Long-term outcomes of laparoscopic versus open D2 gastrectomy for advanced gastric cancer. Surgical oncology. 27(2018)441-448.

21. Norero E, Vargas C, Achurra P, Ceroni M, Mejia R, Martinez C et al. SURVIVAL AND PERIOPERATIVE MORBIDITY OF TOTALLY LAPAROSCOPIC VERSUS OPEN GASTRECTOMY FOR EARLY GASTRIC CANCER: ANALYSIS FROM A SINGLE LATIN AMERICAN CENTRE. Arq Bras Cir Dig. 2019 Jan 7;32(1):e1413.

22. Huawen Wu, Wenhuan Li, Guofu Chen, Weijun Wang, Zhijian Zheng, Jianfeng $\mathrm{Li}$ et al. Outcome of laparoscopic total gastrectomy for gastric carcinoma. JBUON 2016; 21(3): 603-608

23. Xu Y, Hua J, Li J, Shi L, Xue H, Shuang J et al. Long-term outcomes of laparoscopic versus open gastrectomy for advanced gastric cancer: A large cohort study. Am J Surg. 2019 Apr;217(4):750-756. 
24. Hayemin Lee „Junhyun Lee. Long-term outcome of laparoscopic versus open total gastrectomy for advanced gastric cancer: A propensity score-matched analysis. ournal of Clinical Oncology 2019 37:4_suppl, 77-77

25. Kinoshita T, Uyama I, Terashima M, Noshiro H, Nagai E, Obama K et al. Long-term Outcomes of Laparoscopic Versus Open Surgery for Clinical Stage II/III Gastric Cancer: A Multicenter Cohort Study in Japan (LOC-A Study). Ann Surg. 2019 May;269(5):887-894.

26. Iwanaka T, Arkovitz MS, Arya G, Ziegler MM. Evaluation of opera- tive stress and peritoneal macrophage function in minimally invasive operations. J Am Coll Surg 1997;184:357-63.

27. Gupta A, Watson DI. Effect of laparoscopy on immune function. Br J Surg 2001;88:1296-306.

28. Schwenk W, Bohm B, Muller JM. Postoperative pain and fatigue af- ter laparoscopic or conventional colorectal resections: a prospective randomized trial. Surg Endosc 1998;12:1131-6.

29. Glavic Z, Begic L, Simlesa D, Rukavina A. Treatment of accute cholecystitis. A comparison of open vs laparoscopic cholecystecto- my. Surg Endosc 2001;15:398-401.

30. Reza MM, Blasco JA, Andradas E, Cantero R, Mayol J. Systematic review of laparoscopic versus open surgery for colorrectal cancer. $\mathrm{Br} \mathrm{J}$ Surg 2006;93:921-8.

31. Campillo-Soto A, Torralba-Martínez JA, Martín-Lorenzo JM, Lirón- Ruiz R, Bento-Gerard M, Pérez-Cuadrado E, et al. Gastrojejunal anastomosis stricture after laparoscopic gastric bypass. Our experi- ence with 62 patients. Rev Esp Enferm Dig 2010;102:187-92. 
32. Ibáñez Aguirre FJ, Azagra JS, Erro Azcárate ML, Goergen M, Rico Selas P, Moreno Elola-Olaso A, et al. Laparoscopic gastrectomy for gastric adenocarcinoma. Long-term results. Rev Esp Enferm Dig 2006;98:491-500.

33. Lam S, Tan E, Menezes A, Martin D, Gallagher J, Storey D, Sandroussi C. A comparison of the operative outcomes of D1 and D2 gastrectomy performed at a single Western center with multiple surgeons: a retrospective analysis with propensity score matching. World J Surg Oncol. 2018 Jul 9;16(1):136.

34. Uslu A, Zengel B, İlhan E, Aykas A, Şimşek C, Üreyen O, et al. Survival outcomes after D1 and D2 lymphadenectomy with R0 resection in stage II-III gastric cancer: Longitudinal follow-up in a single center. Turk J Surg. 2018 Jul 1;34(2):125-130.

Table 1 charecteristics of studies for short term out comes

\begin{tabular}{|l|l|l|l|}
\hline Study & Type of study & $\begin{array}{l}\text { Number of patients } \\
\text { laproscopic } \\
\text { gastrectomy }\end{array}$ & Number of patients \\
in open group \\
\hline KLASS02 & RCT & 513 & 498 \\
\hline $\begin{array}{l}\text { Cristiano } \\
2005\end{array}$ & RCT & 30 & 29 \\
\hline $\begin{array}{l}\text { HU } \\
2016\end{array}$ & RCT & 519 & 520 \\
\hline LEE 2004 & RCT & 24 & 23 \\
\hline HIYASHI 2005 & RCT & 14 & 14 \\
\hline KITANO 2002 & RCT & 14 & 14 \\
\hline $\begin{array}{l}\text { KIM } \\
2016\end{array}$ & RCT & 686 & 698 \\
\hline $\begin{array}{l}\text { Cia } \\
2011\end{array}$ & RCT & 49 & 47 \\
\hline
\end{tabular}




\begin{tabular}{|l|l|l|l|}
\hline $\begin{array}{l}\text { Takiguchi } \\
2013\end{array}$ & RCT & 20 & 20 \\
\hline $\begin{array}{l}\text { Cui } \\
2015\end{array}$ & RCT & 128 & 142 \\
\hline katai2017 & RCT & 455 & 157 \\
\hline
\end{tabular}

Figure legends:

Figure 1 search strategy for short term and long term outcomes.

Figure 2: Risk of bias summary of RCT. + denotes low risk of bias, - denotes high risk of bias.

Figure 3. Comparision between morbidity and mortality between laproscopic and open gastrectomy.

Figure 4. There was no significant difference between intraadbominal,systemic and wound complications between laproscopic and open gastrectomy.

Figure 5 comparisons of blood loss, hospital stay and operative time between laproscopic and open gastrectomy.

Figure 6 comparisons of completion of d2 gastrectomy,number of lymphnode retrived and T2 and high staging between laproscopic and open gastrectomy 
medRxiv preprint doi: https://doi.org/10.1101/2020.04.12.20062562; this version posted September 17, 2020. The copyright holder for this preprint (which was not certified by peer review) is the author/funder, who has granted medRxiv a license to display the preprint in perpetuity.

It is made available under a CC-BY 4.0 International license .

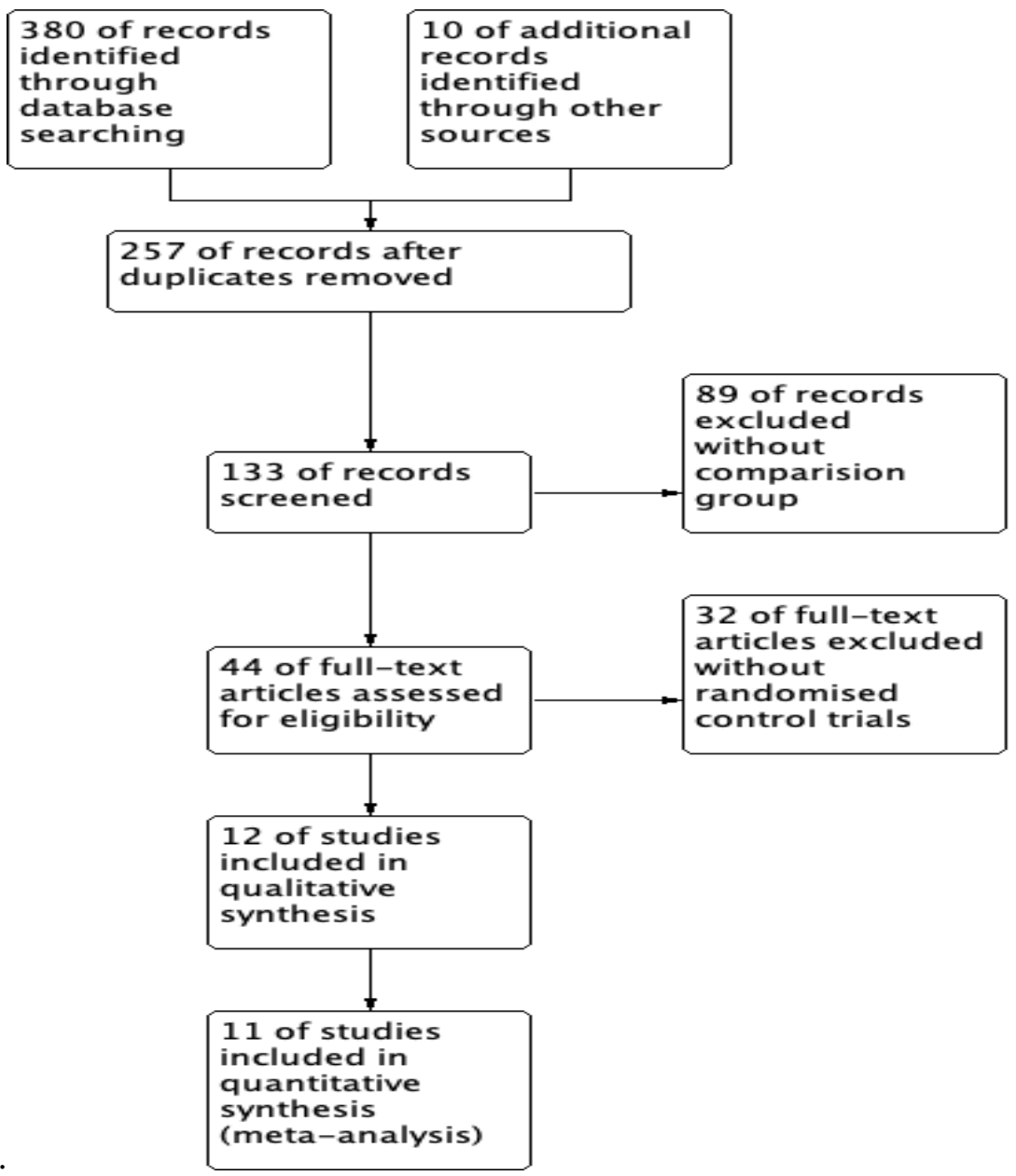

Search strategy according to PRISMA guidelines for short term outcomes 


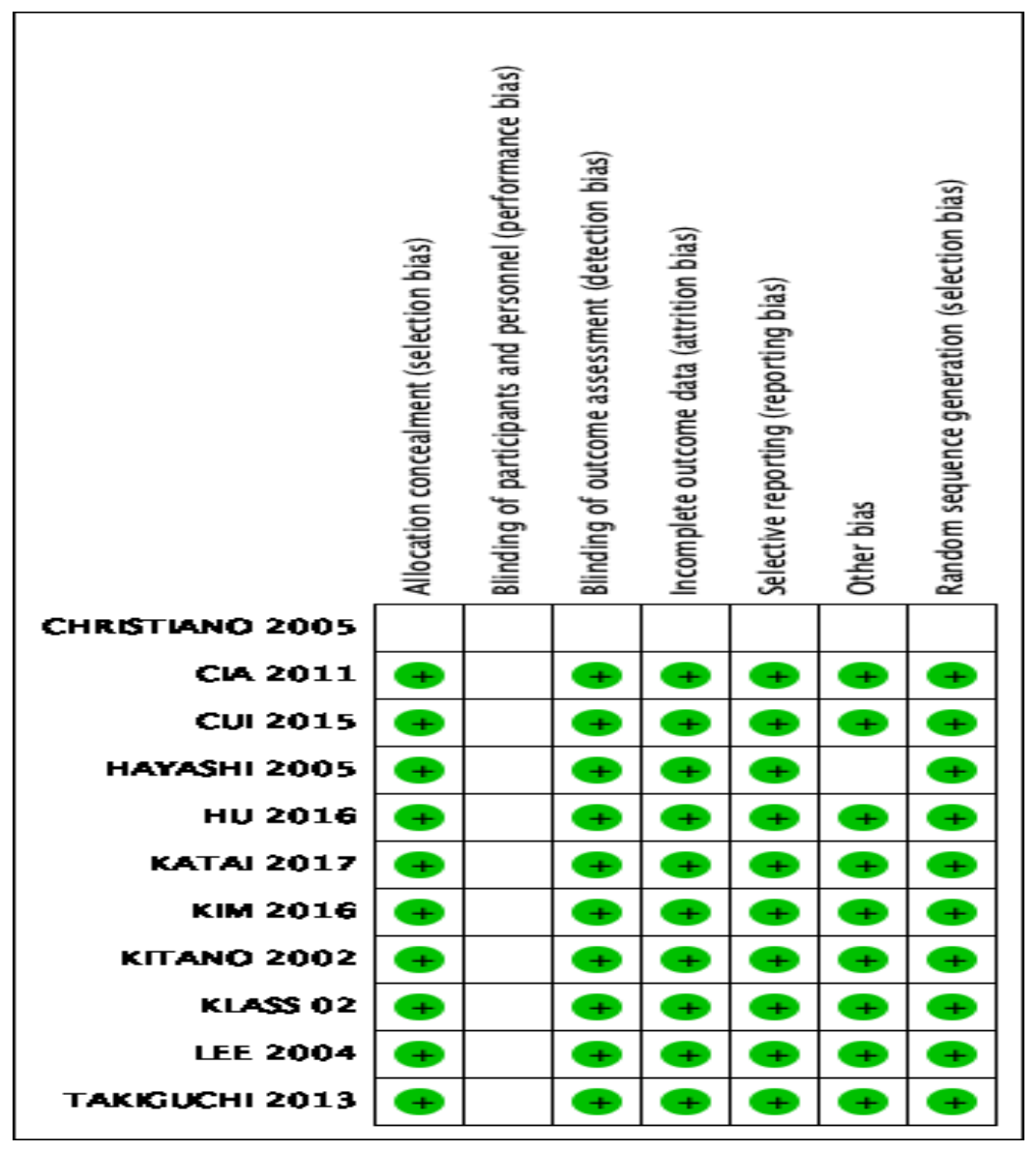

Figure 2: Risk of bias summary of RCT. + denotes low risk of bias, - denotes high risk of bias.

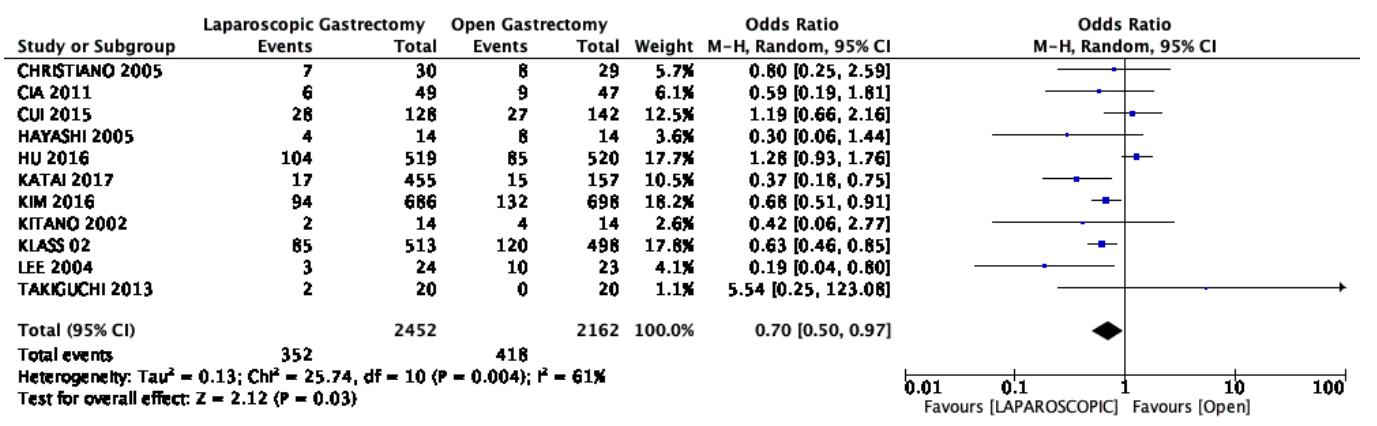

Figure 3(a) 
medRxiv preprint doi: https://doi.org/10.1101/2020.04.12.20062562; this version posted September 17, 2020. The copyright holder for this preprint (which was not certified by peer review) is the author/funder, who has granted medRxiv a license to display the preprint in perpetuity.

It is made available under a CC-BY 4.0 International license .

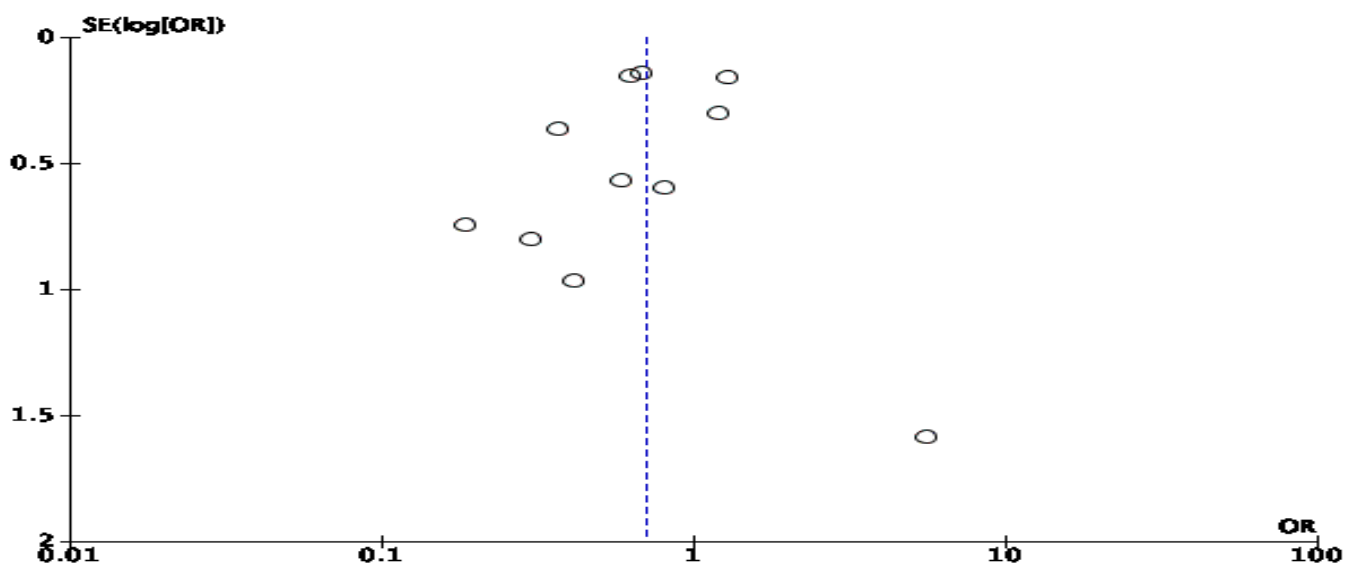

Figure 3(b)

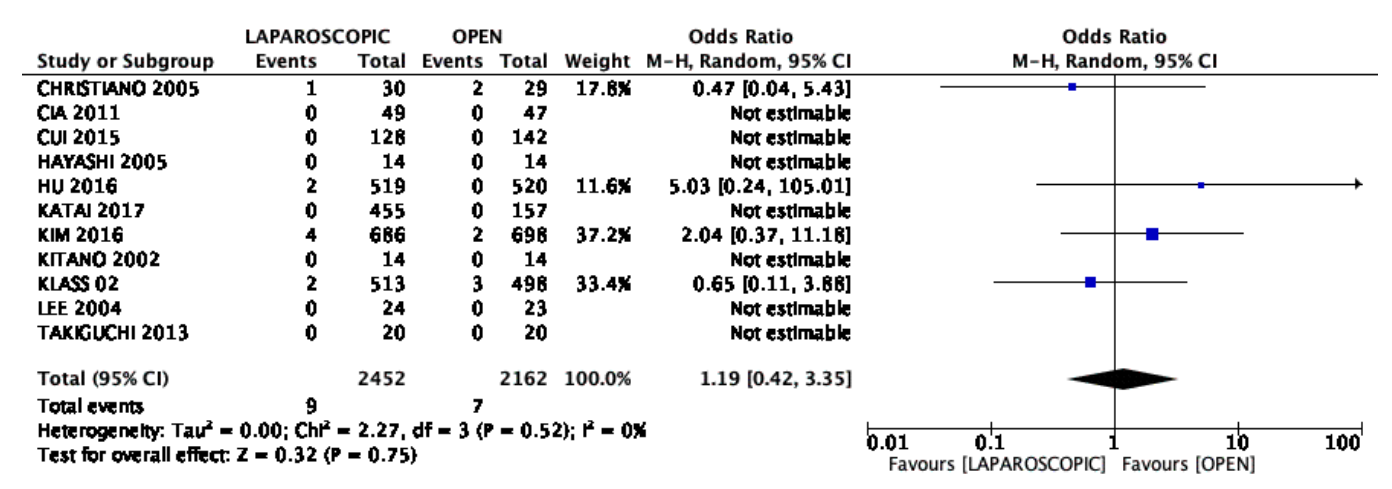

Figure 3(c)

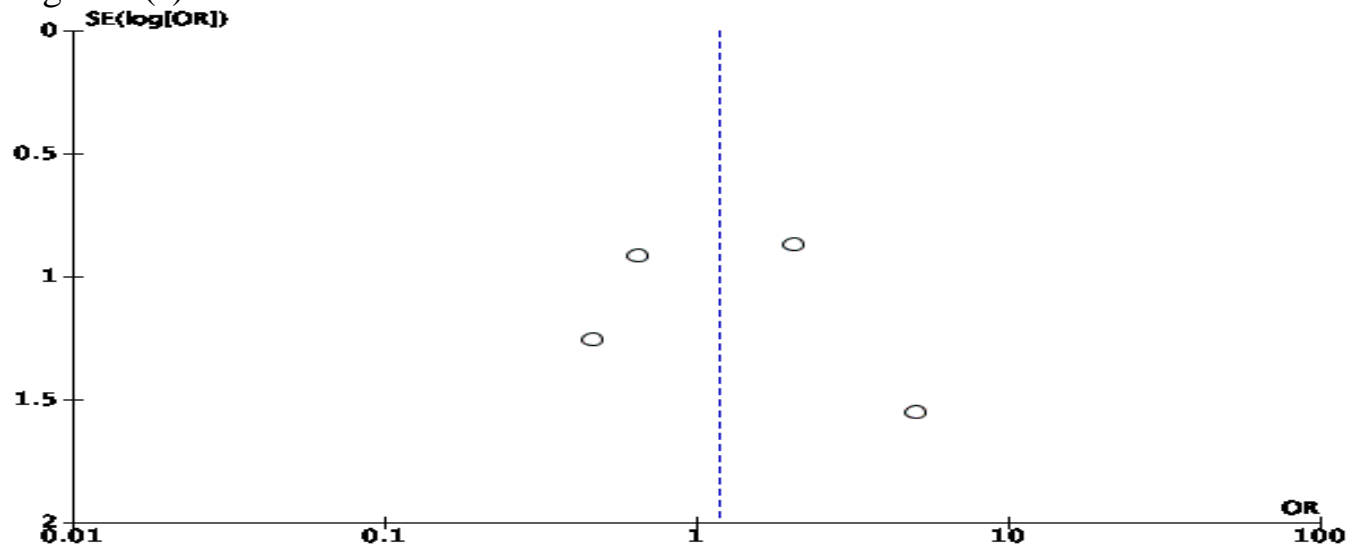

Figure 3(d)

Figure 3. (a)Comparision between morbidity laproscopic and open gastrectomy. (b) Funnel point of morbidity (c) Forest plot of mortality between laparoscopic and open gastrectomy (d) Funnel plot of mortality. 
medRxiv preprint doi: https://doi.org/10.1101/2020.04.12.20062562; this version posted September 17, 2020. The copyright holder for this preprint (which was not certified by peer review) is the author/funder, who has granted medRxiv a license to display the preprint in perpetuity.

It is made available under a CC-BY 4.0 International license .

\begin{tabular}{|c|c|c|c|c|c|}
\hline \multirow[b]{2}{*}{ Study or Subgroup } & \multicolumn{2}{|c|}{ LAPAROSCOPIC } & \multicolumn{2}{|c|}{ OPEN } & \multirow[b]{2}{*}{ Weight $\mathrm{N}$} \\
\hline & Events & Total & Events & Total & \\
\hline CHRISTIANO 2005 & 2 & 30 & 2 & 29 & $2.7 \%$ \\
\hline CIA 2011 & 1 & 49 & 1 & 47 & $1.4 \%$ \\
\hline CUI 2015 & 0 & 128 & 1 & 142 & $1.1 \mathrm{x}$ \\
\hline HAYASHI 2005 & 0 & 14 & 0 & 14 & \\
\hline HU 2016 & 6 & 519 & 5 & 520 & $7.9 \times$ \\
\hline KATAI 2017 & 2 & 455 & 1 & 157 & $2.0 \times$ \\
\hline KIM 2016 & 25 & 686 & 49 & 698 & $46.4 \%$ \\
\hline KTTANO 2002 & 0 & 14 & 0 & 14 & \\
\hline KLASS 02 & 23 & 513 & 29 & 493 & $35.8 x$ \\
\hline LEE 2004 & 1 & 24 & 1 & 23 & $1.4 \%$ \\
\hline TAKKGUCHI 2013 & 0 & 20 & 2 & 20 & $1.2 \%$ \\
\hline Total $(95 \% \mathrm{Cl})$ & & 2452 & & 2162 & $100.0 \%$ \\
\hline $\begin{array}{l}\text { Total events } \\
\text { Heterogenelty: } \\
\text { Test for overall }\end{array}$ & $\begin{array}{l}60 \\
\mathrm{Ch}^{-1}\end{array}$ & & $\begin{array}{r}91 \\
=8 \text { (P }\end{array}$ & & \\
\hline
\end{tabular}

Odds Ratio

Odds Ratio

, Random, 95\% CI

$0.96[0.13,7.34]$

$0.96[0.06,15.78]$

$0.37[0.01,9.09]$

Not estimable

$1.20[0.37,3.97]$

$0.69[0.06,7.65]$

$0.50[0.31,0.82]$

Not estimable

$0.76[0.43,1.33]$

$0.96[0.06,16.25]$

$0.18[0.01,4.01]$

$0.64[0.46,0.90]$

Test for overall effect: $Z=2.60(\mathrm{P}=0.009)$

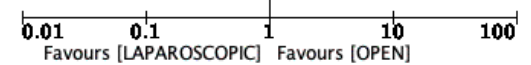

Figure 4(a) Wound complications Forest plot.

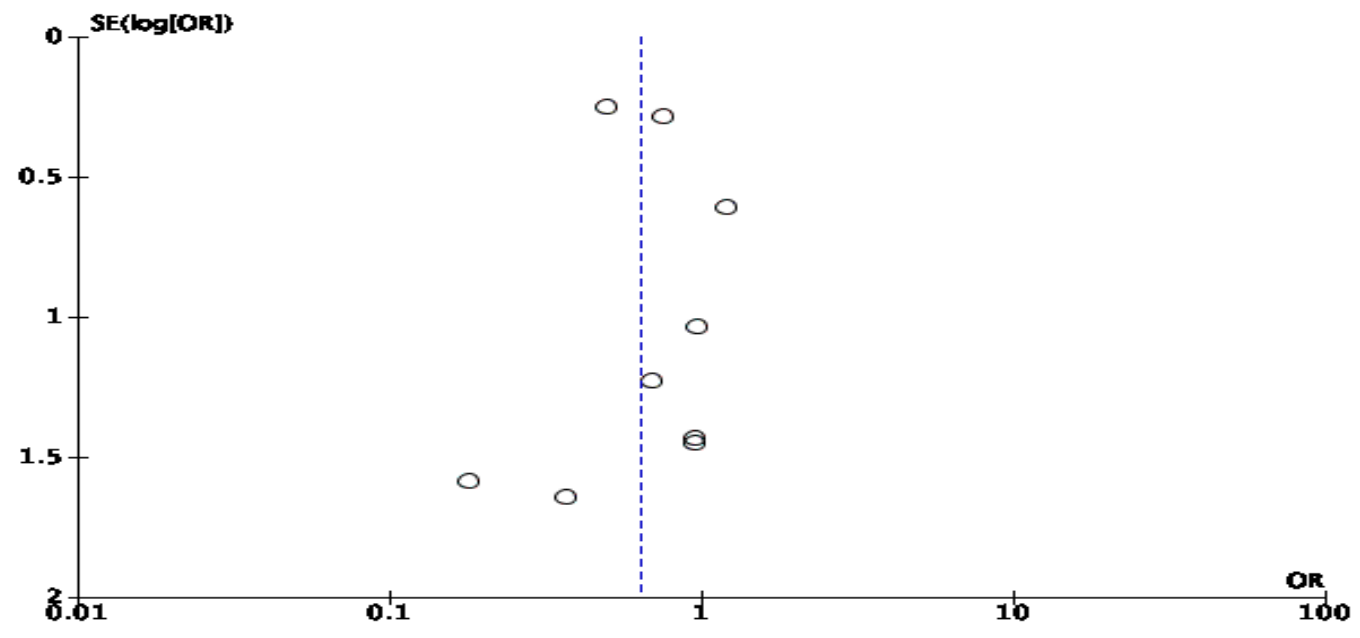

Figure 4 (b) Funnel plot Wound Complications.

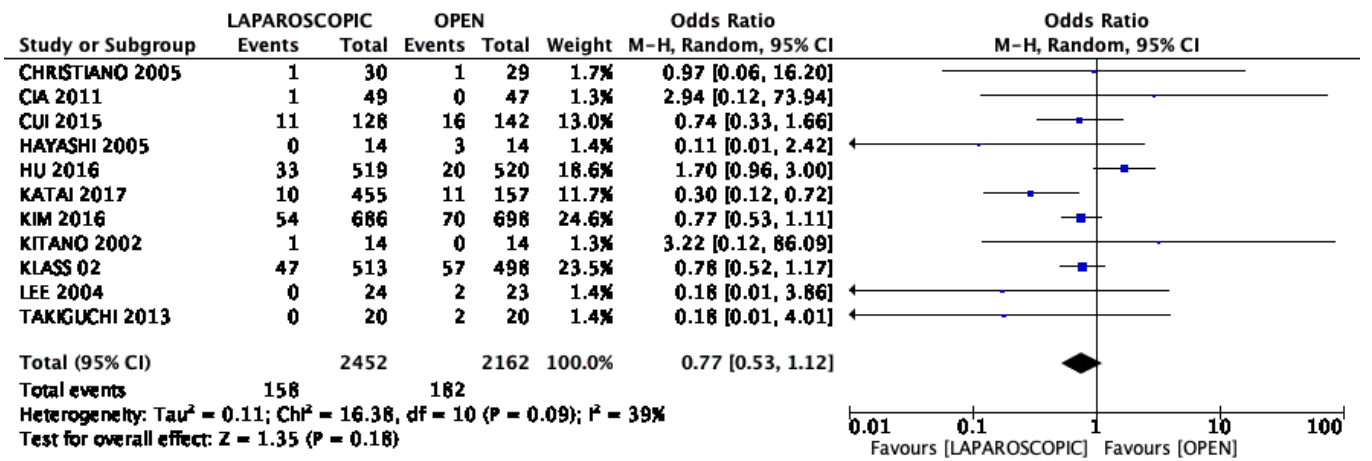

Figure 4 (c) Forest Plot abdominal complications. 


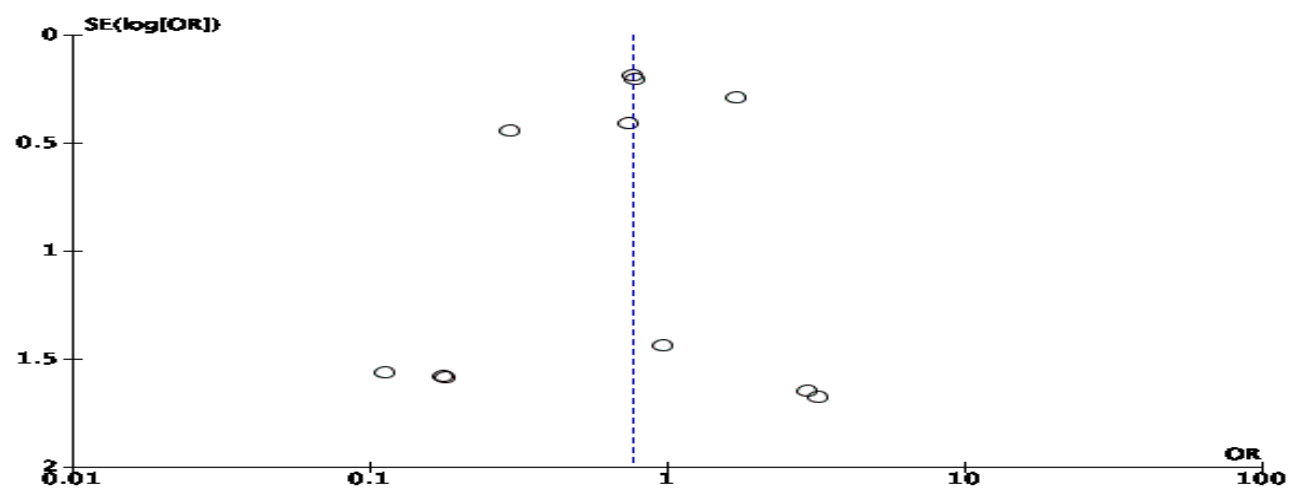

Figure 4(d) Funnel Plot abdominal complications.

Figure 4: wound complications was significantly less but no difference in intraabdominal complications.

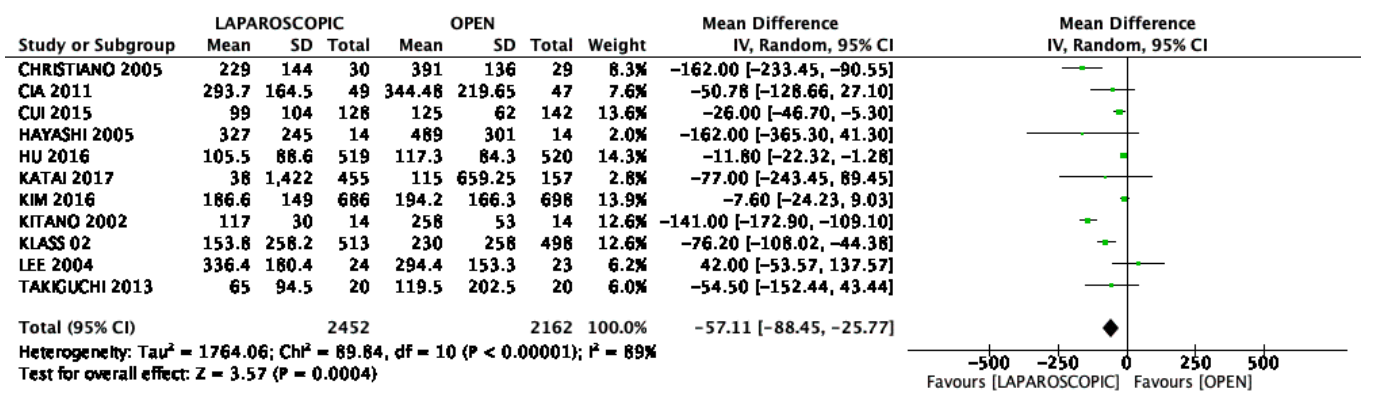

Figure 5 (a) Forest Plot blood loss.

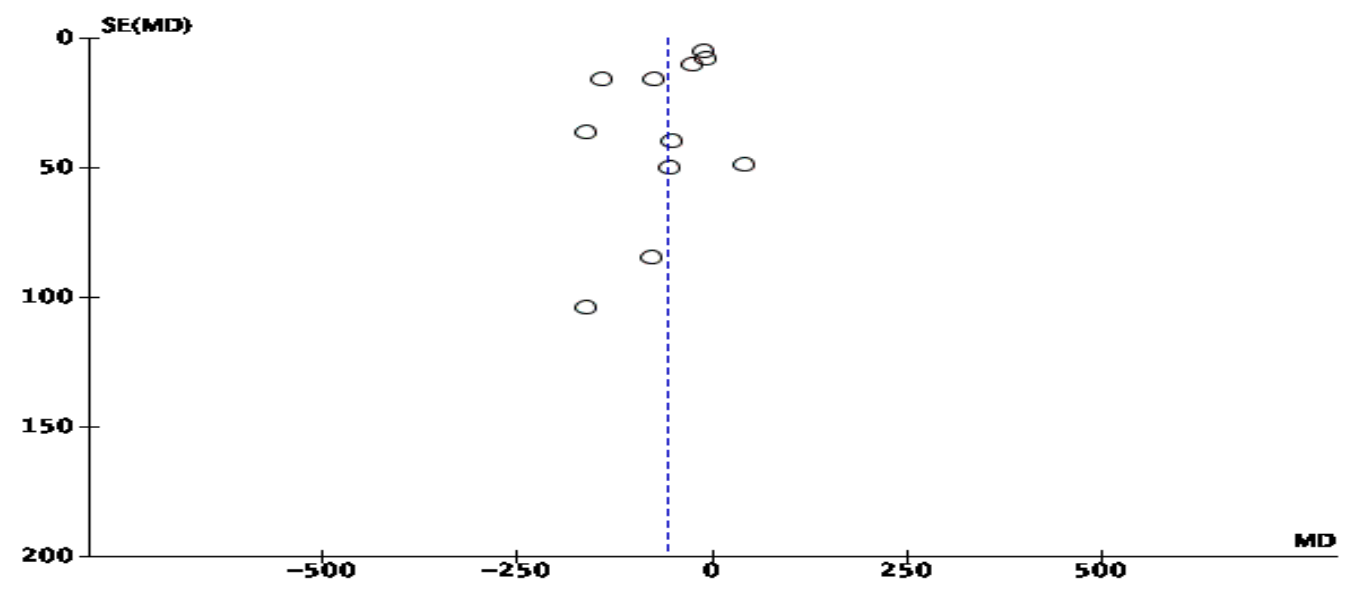

Figure 5(b) Funnel Plot of blood loss. 
medRxiv preprint doi: https://doi.org/10.1101/2020.04.12.20062562; this version posted September 17, 2020. The copyright holder for this preprint (which was not certified by peer review) is the author/funder, who has granted medRxiv a license to display the preprint in perpetuity.

It is made available under a CC-BY 4.0 International license .

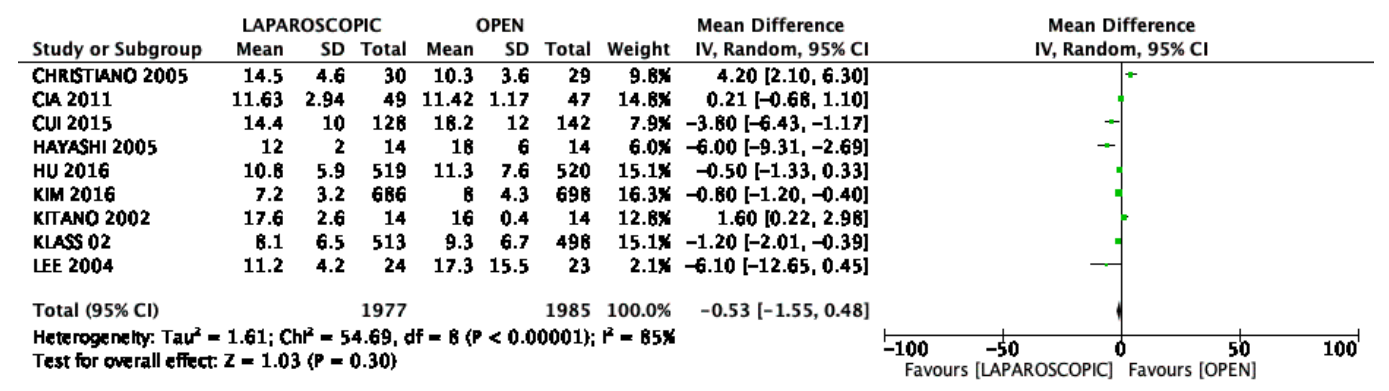

Figure 5(c) Forest Plot Hospital stay.

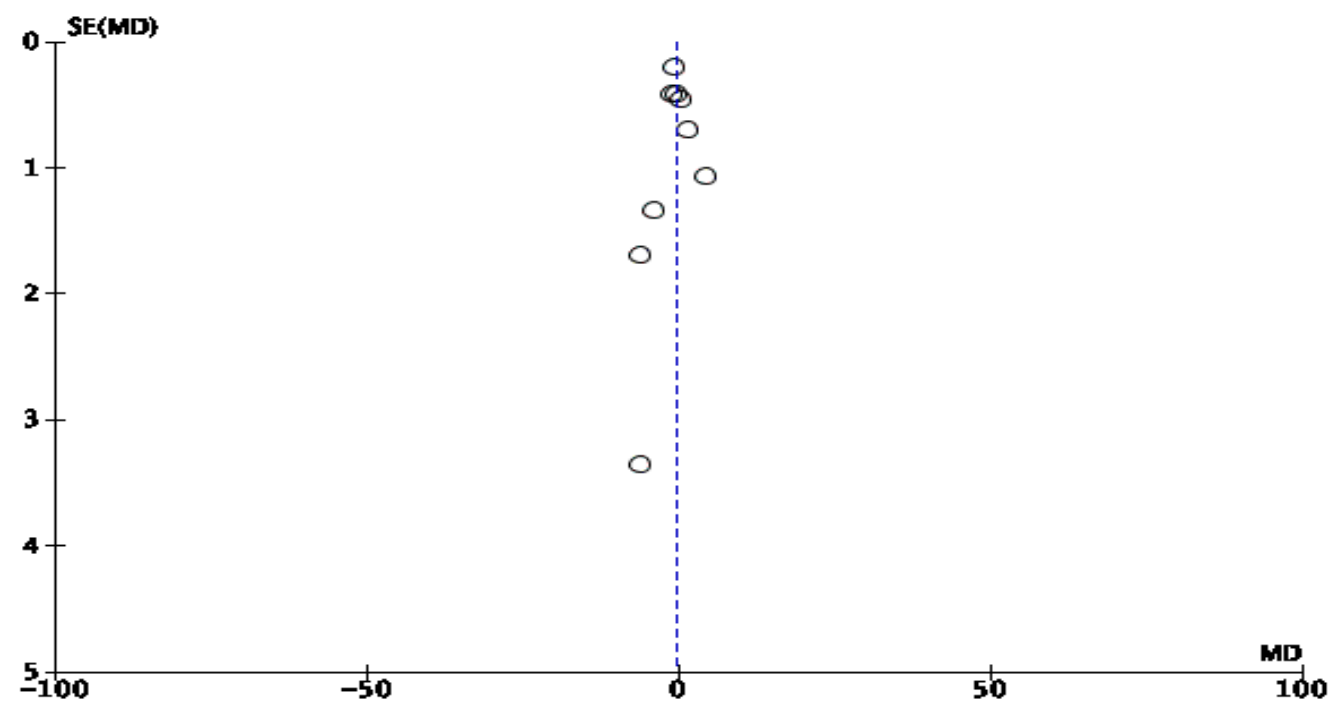

Figure 5(d) Funnel Plot Hospital stay.

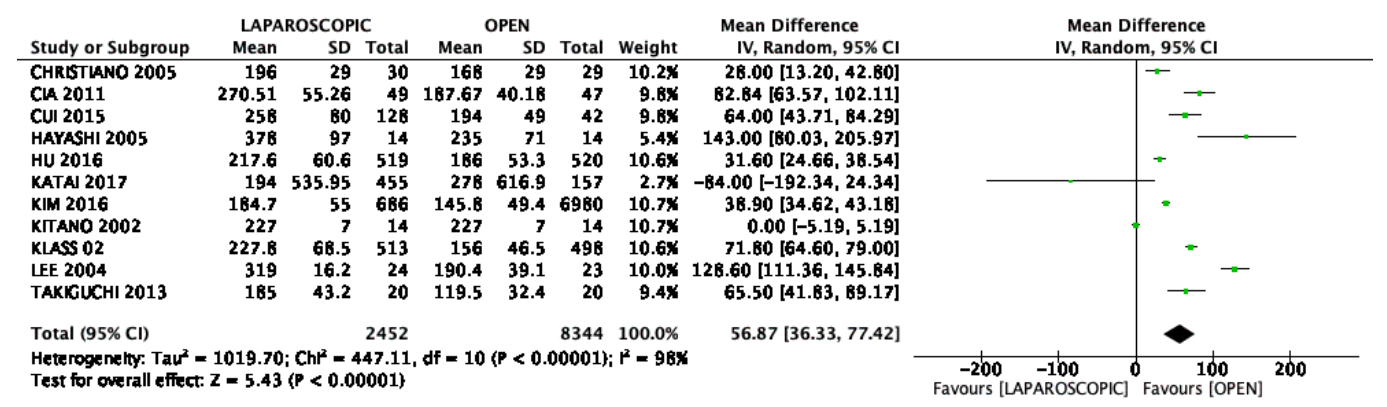

Figure 5(e) Forest Plot Operative time. 
medRxiv preprint doi: https://doi.org/10.1101/2020.04.12.20062562; this version posted September 17, 2020. The copyright holder for this preprint (which was not certified by peer review) is the author/funder, who has granted medRxiv a license to display the preprint in perpetuity. It is made available under a CC-BY 4.0 International license .

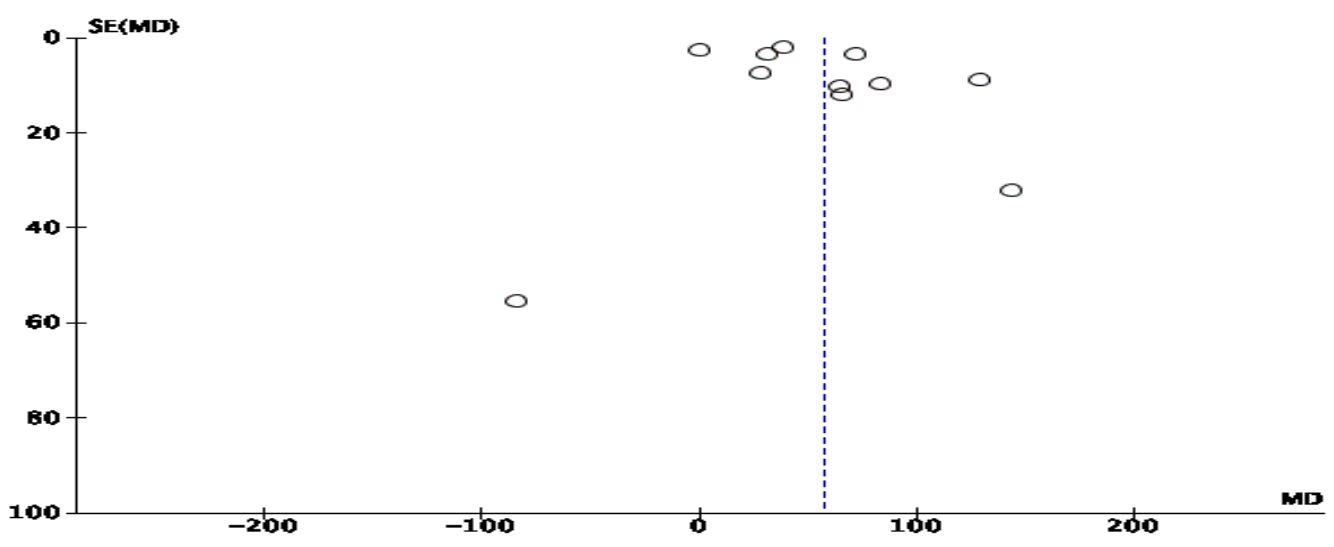

Figure 5 (f) Funnel Plot Operative Time

Figure 5: Comparisons of blood loss, hospital stay and operative time between laproscopic and open gastrectomy.

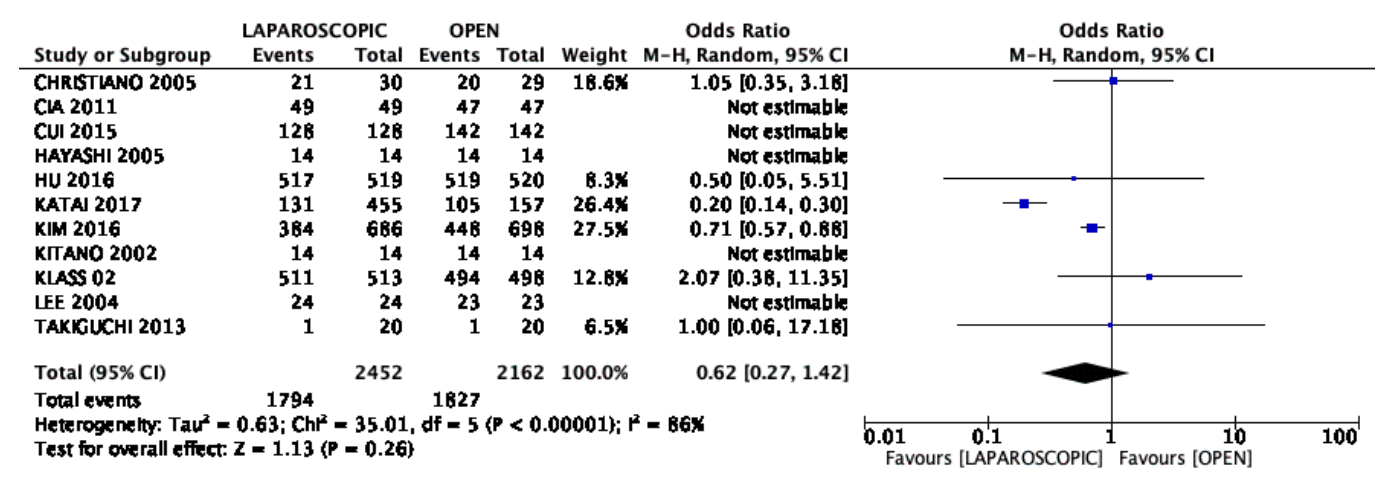

Figure 6(a) Forest Plot of D2 gastrectomy . 
medRxiv preprint doi: https://doi.org/10.1101/2020.04.12.20062562; this version posted September 17, 2020. The copyright holder for this preprint (which was not certified by peer review) is the author/funder, who has granted medRxiv a license to display the preprint in perpetuity.

It is made available under a CC-BY 4.0 International license .

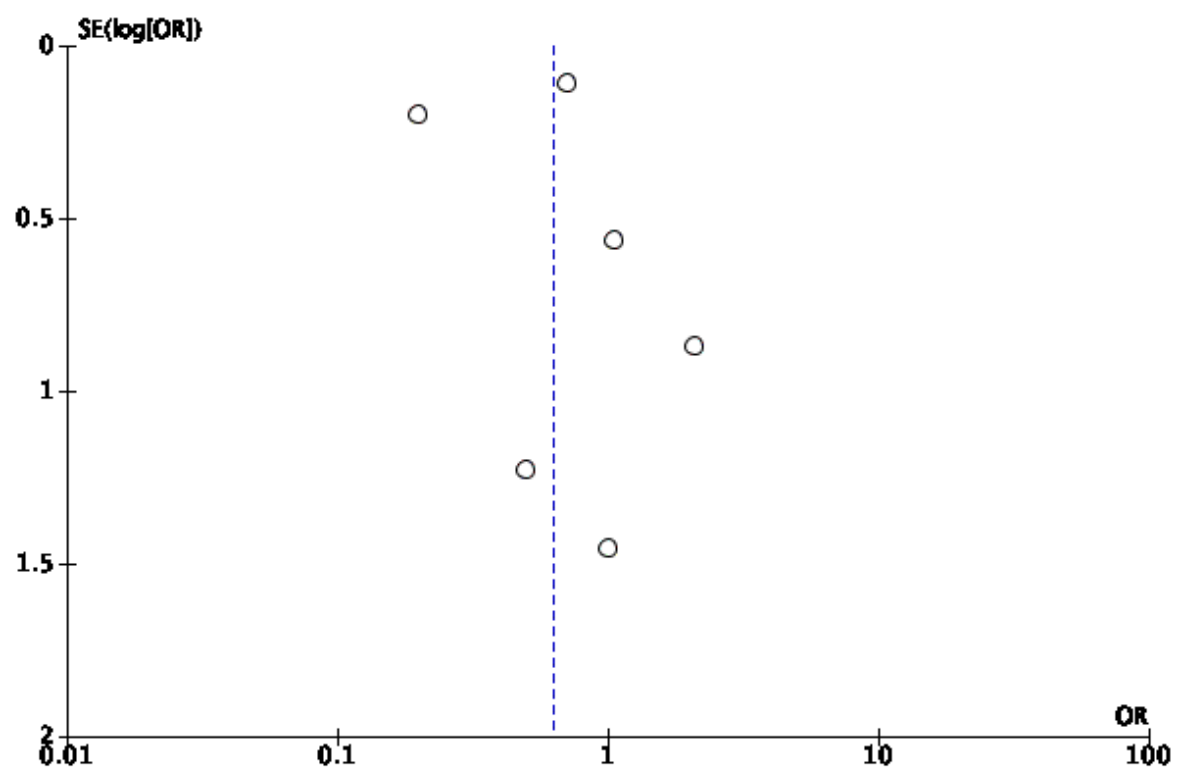

Figure 6 (b) Funnel Plot of D2 gastrectomy.

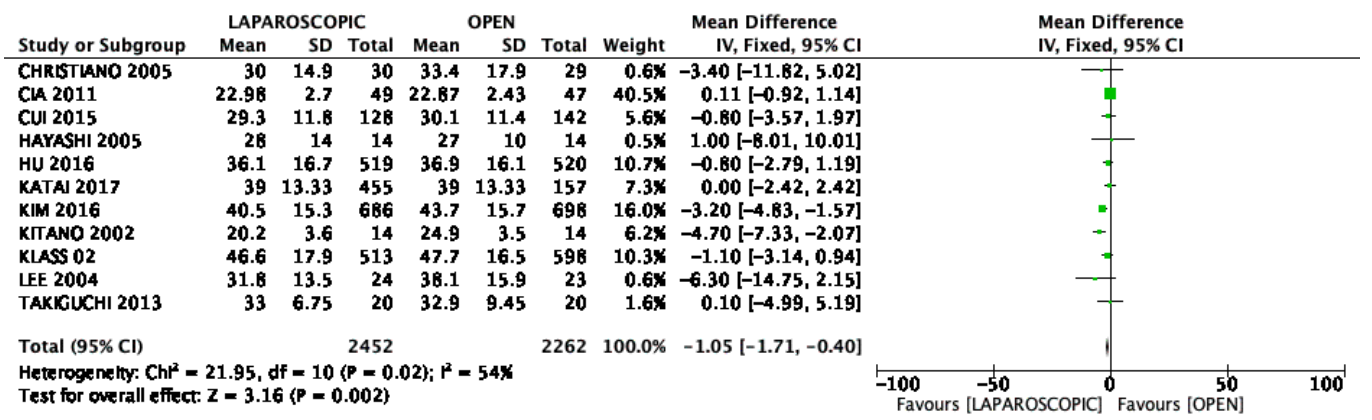

Figure 6(c) Forest plot for lymphnode retriveal

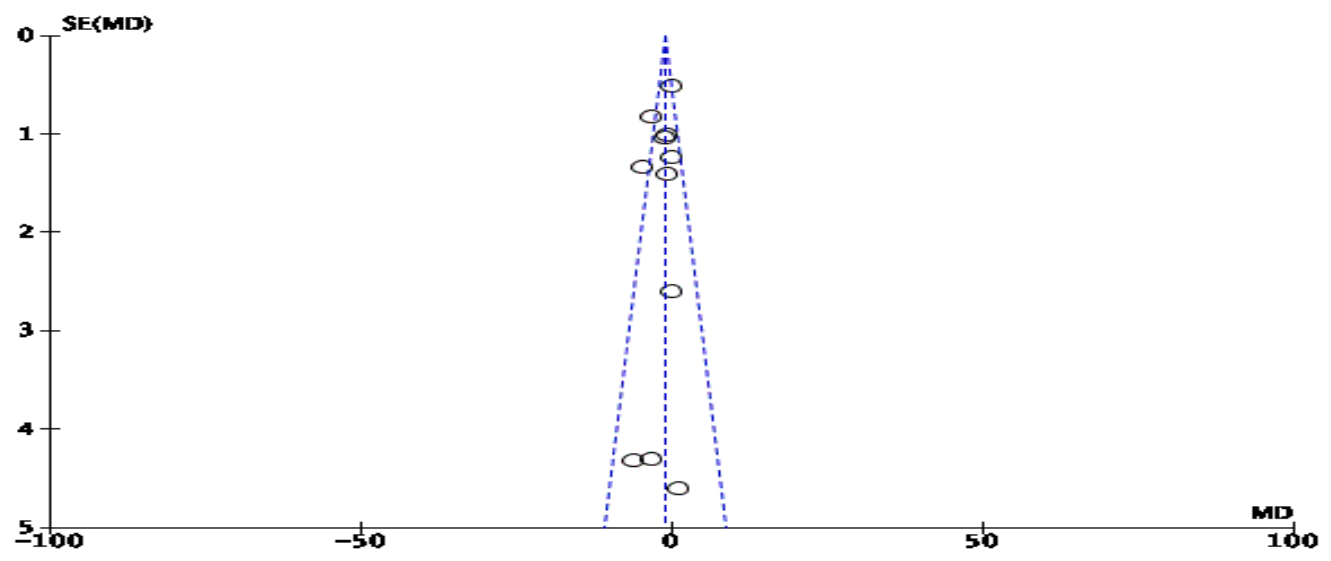

Figure 6(d) Funnel plot for lymphnode retriveal. 
medRxiv preprint doi: https://doi.org/10.1101/2020.04.12.20062562; this version posted September 17, 2020. The copyright holder for this preprint (which was not certified by peer review) is the author/funder, who has granted medRxiv a license to display the preprint in perpetuity.

It is made available under a CC-BY 4.0 International license .

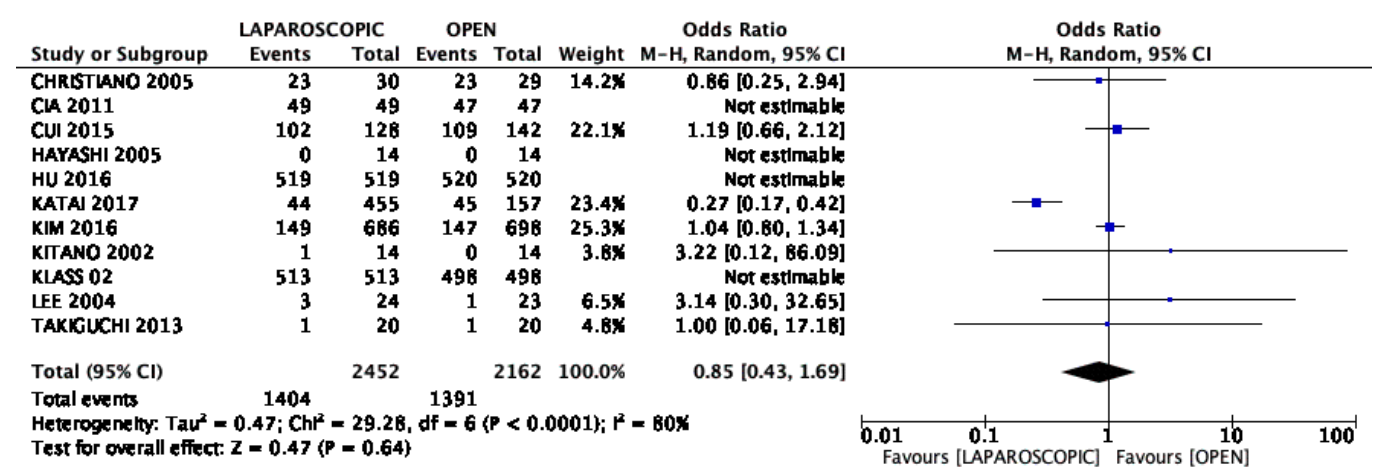

Figure 6 (e) Forest plot Comparisons of T2 and higher staging between laproscopic and open gastrectomy.

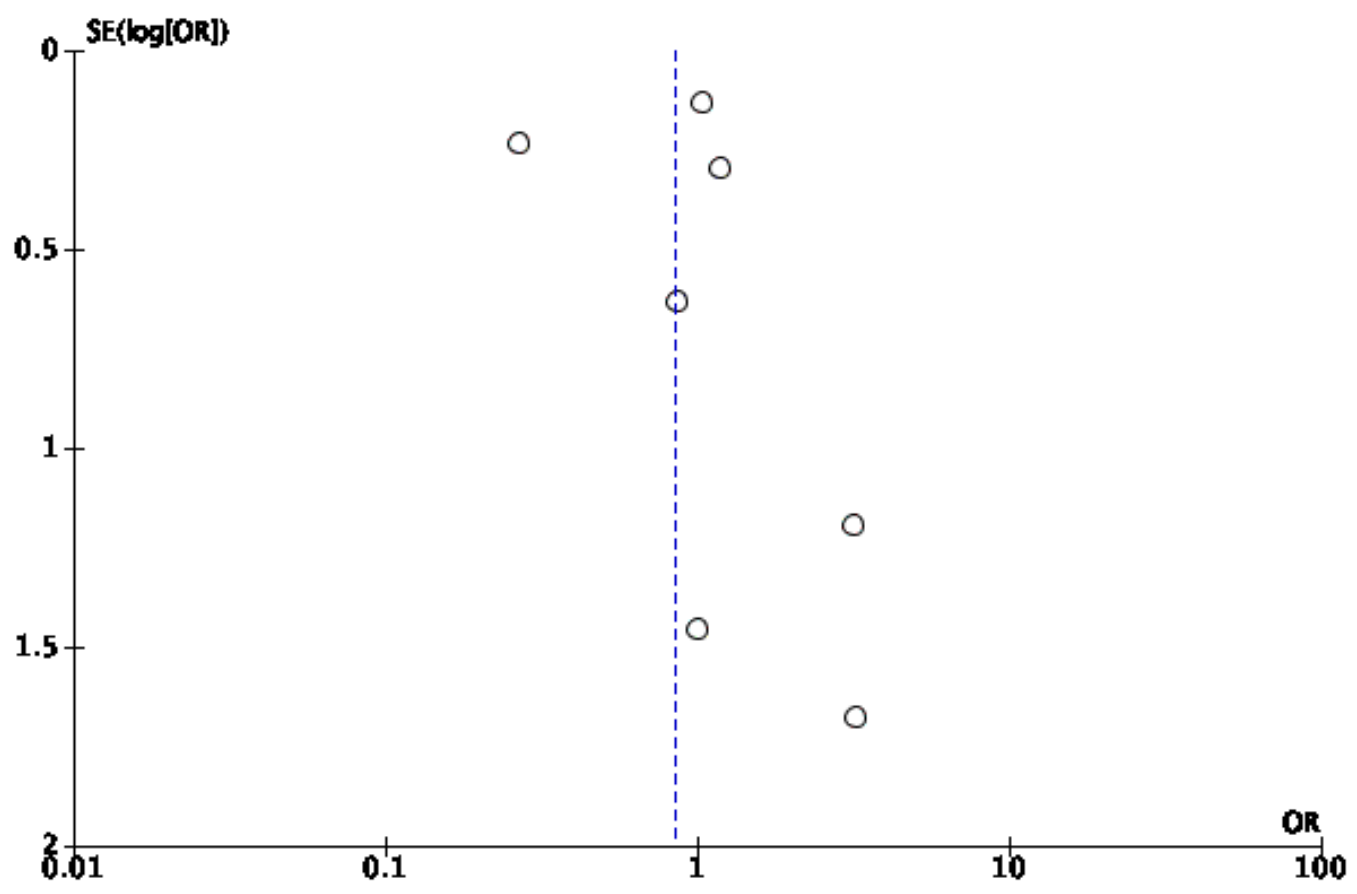

Figure 6(f) Funnel Plot for T2 and higher staging.

Figure 6. comparision of completion of $\mathrm{d} 2$ gastrectomy,number of lymphnode retrived and T2 and high staging between laproscopic and open gastrectomy 